\title{
Ranch Apocalypse: A Pataphysical Inquiry into the Mount Carmel Siege
}

\author{
Michelle Granden*
}

\author{
Department of Psychology, University of West Georgia, USA
}

\begin{abstract}
A total of 84 people were killed in the 1993 Bureau of Alcohol, Tobacco, and Firearms (ATF) raid on Mount Carmel in Waco, Texas. Debates continue about who was responsible-e.g., was it a government conspiracy or cultist militants intent on mass suicide? What hasn't been fully considered, however, is the role the guns, tanks, toxic gases, and other "theater of war" accoutrements themselves played in the siege and resultant deadly inferno. Traditional metaphysical inquiries rest on the presupposition that the subject is separate from and sovereign over the object it examines. But as we have entered this intensely visual consumer culture, differences between subject and object disappear and the power of the subject collapses. Employing the postmodern metaphysics-here and elsewhere called "pataphysics" - of Jean Baudrillard to investigate this tragic battle, the author will argue that the ATF and the FBI were seduced by the compound's castle and arsenal as well as their own. The helicopters, snipers, tanks, and CS gas turned what had begun on February 28, 1993, as a raid to serve a search warrant into a full scale military-style attack on a fortress and its peoples. Could it be that the federal agents became and were subordinate to the tools they were using?
\end{abstract}

Keywords: Baudrillard, Branch Davidians, metaphysics, pataphysics, postmodernism, sect, visual culture.

\section{RANCH APOCALYPSE ${ }^{1}$ : A PATAPHYSICAL INQUIRY INTO THE MOUNT CARMEL SIEGE}

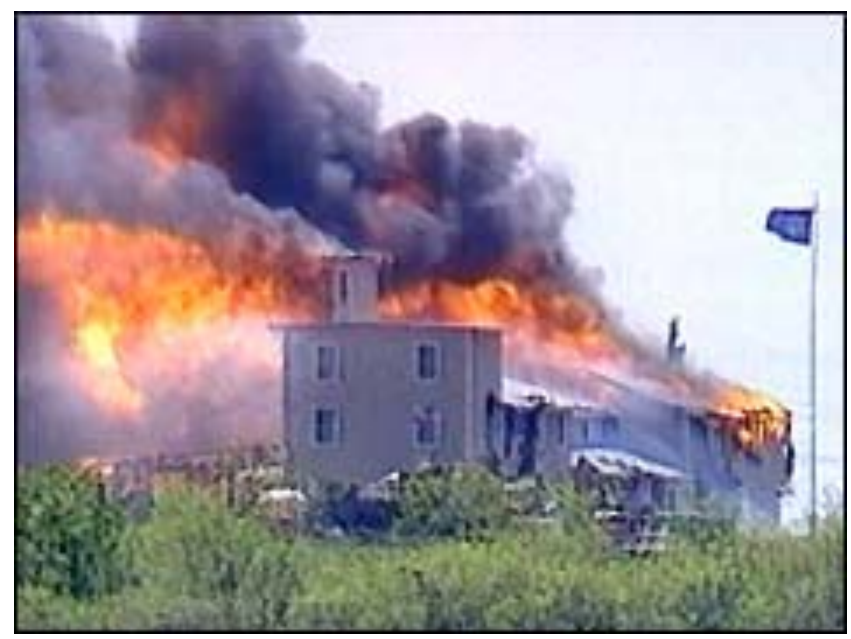

Figure 1: Deadly fire at Mount Carmel after the siege (BBC News 1993).

"[Evil] is expressed in the cunning genius of the object, in the ecstatic form of the pure object, and in its victorious strategy over the subject."

$$
\text { -Jean Baudrillard (1988b:185) }
$$

By April 19, 1993, a total of 84 people were dead in Waco, Texas: 4 federal agents and 80 members of the

\footnotetext{
*Address correspondence to this author at the Department of Psychology, University of West Georgia, Carrollton, GA 30118, USA;

Tel: 678-839-6510; Fax: 678-839-0611; E-mail: mgranden@westga.edu
}

\footnotetext{
${ }^{1}$ "Ranch Apocalypse" is what David Koresh portentously termed the ATF and FBI siege upon his Mount Carmel compound before he and his remaining followers were killed.
}

religious group, the Branch Davidians, including 21 children and the sect's leader, David Koresh (Wright 1995:76). The battle began on February 28, 1993, when the Bureau of Alcohol, Tobacco, and Firearms (ATF) raided the Davidians' Mount Carmel compound, where a shootout ensued that killed 4 ATF agents and 6 Davidians. This initiated a 51-day standoff between the Davidians and the Federal Bureau of Investigation (FBI).

Debates continue about what led to this-one of the deadliest law enforcement operations in U. S. historyand who was responsible (e.g., government conspiracy or cultist militants intent on mass suicide). What has been overlooked, however, is the role the guns, tanks, toxic gases, and other "theater of war" accoutrements themselves played in the siege and resultant deadly inferno. That is not to say that the weapons merely facilitated or amplified the human-driven drama. Rather, is it possible that the objects themselves called for and commanded the conflict? Do objects have strategies all their own?

\section{SEDUCTION OF THE OBJECT}

Traditional metaphysical inquiries rest on the presupposition that the subject is, first of all, separate from the object it examines; and secondly that the subject has sovereignty over the object. But as we have entered this intensely visual consumer culture-a hyperreality embedded in which is what sociologist Joann Finkelstein (2007:27) calls the "visualization of identity"-differences between subject and object, and between interior and exterior, disappear and the power of the subject collapses. Cultural anthropologist Ernest 


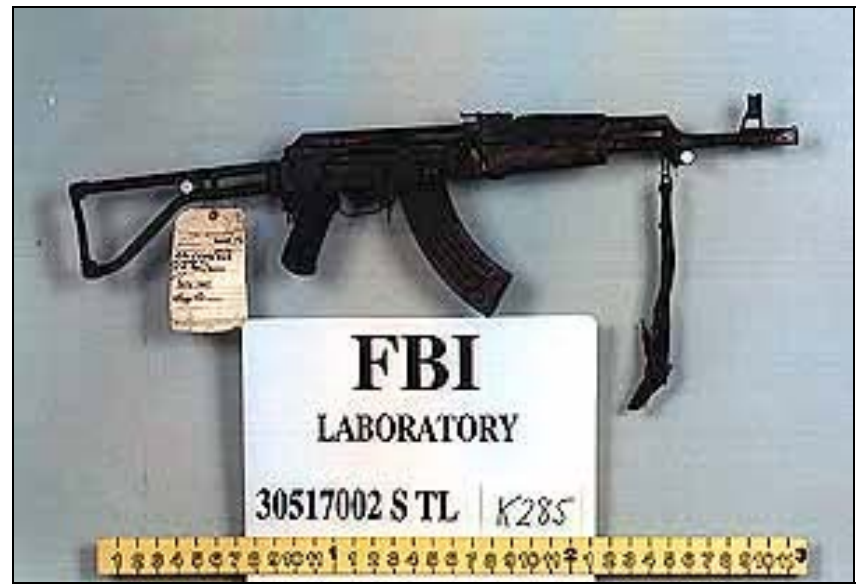

Figure 2: Evidence photo of assault rifle seized from Davidians (Waco: The Rules of Engagement 2010a).

Becker ([1962] 1971:33) sees the new subjectivity like this: "the self overflows and extends into the surroundings, as a kind of huge amoeba, pushing its pseudopods to a wife, a car, a flag, a crushed flower in a secret book." Perhaps these things beckon us, seduce us, pull us into their own system of suggestibility and control.

Where alterity and otherness break down, where the secret of things disappears and there is now an engulfing "over-proximity of all things," as Baudrillard ([1987] 1988a:27) says, the subject extends its subjectivity into the object. Furthermore, it is not the desire of the subject which directs this; it is the seduction of the object. Baudrillard ([1983] 1990:111) asks:

Who has ever sensed the foreboding of the particular and sovereign potency of the object? In our philosophy of desire, the subject retains an absolute privilege, since it is the subject that desires. But everything is inverted if one passes on to the thought of seduction. There, it's no longer the subject which desires, it's the object which seduces. Everything comes from the object and everything returns to it, just as everything started with seduction, not with desire. The immemorial privilege of the subject is overthrown.

The object, then, "becomes the horizon of the subject's disappearance" (Baudrillard 2000:76-77). This twisting of the relations of sovereignty between subject and object calls for a new metaphysics-a "pataphysics"- that can account for this shift toward the dissolution of the subject and the dominion of the object.

\section{MOUNT CARMEL BECKONS}

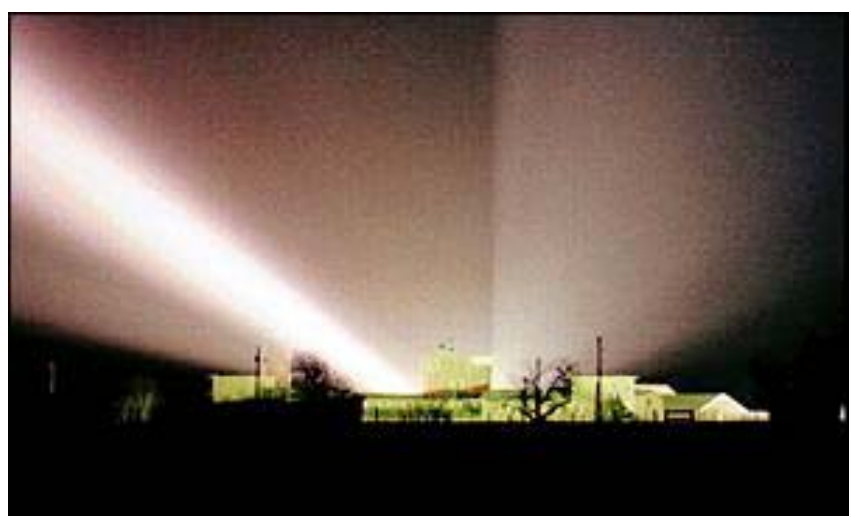

Figure 3: Mount Carmel before the siege (BBC News 1999).

The tragic events at Waco might be said to have begun in 1990 with the construction of Mount Carmel, the isolated commune to be the home of David Koresh's sect of the Branch Davidians. The compound had a bunker with one-foot thick concrete walls, a oneyear supply of food, and was stockpiled with over 240 firearms. On the margins of society, Mount Carmel sat in opposition to the rest of the world. Situated 10 miles outside of town and down several desolate farm roads, the Davidians' center was purposefully split off from mainstream civilization.

The Davidians built what would become their death house. One of the survivors, David Thibodeau, describes the construction of the complex as stemming from David Koresh's sense that "the waters [were] rising around us" (Thibodeau and Whiteson 1999:80). Thibodeau goes on to say,

The new, more compact, perhaps more defensible building was meant to house all those who might decide to join us at Mount Carmel for the coming confrontation with adverse forces. We had to create a solidarity against the dangers David felt were mounting in Babylon. (Thibodeau and Whiteson 1999:80)

Mount Carmel, as a sort of self-contained fortress set apart from society, the law, and all that is secular, invited its invasion. The ATF and FBI could not stand idly by as this compound, housing a self-destructive Messiah, over a hundred of his brainwashed followers, and enough weaponry-allegedly some of which were illegally modified firearms - to equip a small army. The 
guns, the isolation, Mount Carmel itself, were all pregnant with the apocalypse which their prophet foretold. But more than inviting the destruction, perhaps these objects mysteriously governed the events. In fact, the Branch Davidians were described by many who knew them, including the McLennan County Sheriff, as peaceful people (Gazecki 1997). But if the pataphysical subject is no longer in control of its objects, the Davidians couldn't help themselves: Inherent in the guns and the compound was the violent battle that ultimately ensued between Prophecy and The Law.

Eerily, more than 10 years before the siege, David Koresh had a vision of a skyscraper that had inscribed on one wall, "THE LAW," and on another wall "PROPHECY" (Thibodeau and Whiteson 1999:42). The building had the name and intention of the battle written on it before it was ever designed. If this is to be believed, Koresh must be the prophet he professed himself to be. Or maybe this is further testament to the seduction of objects. Baudrillard ([1983] 1990:161) states that objects can strangely, pataphysically, precede the events that cause them to be brought to bear in a way that dissolves normal cause and effect relationships: He says, "The fact that things are in advance of the unfolding of their causes, their precession in time-that is their secret. It is the secret of their seduction..." Absurdly, Mount Carmel literally and figuratively fueled the 1993 holocaust in Waco.

\section{MILITARY TRAPPINGS}

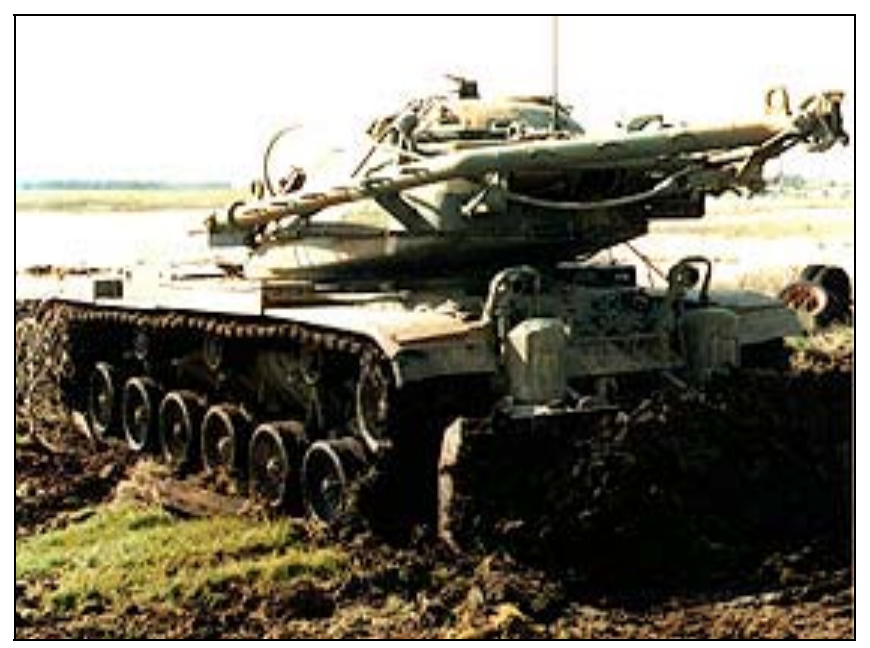

Figure 4: Evidence photo of tank used to inject CS gas (Waco: The Rules of Engagement 2010c).

The Davidians were not the only subjects in this exchange to fall under the spell of the objects. In another instance of the object mysteriously preceding its cause, Thibodeau and Whiteson (1999:267) report that "ominously, two weeks before April 19, the FBI asked morgues in the area to arrange for a special order of around 80 body bags, enough to deal with the corpses of every man, woman, and child remaining in Mount Carmel." The ordering of the body bags might have been a sensible precaution, but it might also have been a forecasting of the objects' secret goal.

The ATF and the FBI were lured by the Mount Carmel citadel and all of the military trappings that went into its conquering. The things were in control, not the people. Federal agents were seduced by Koresh's castle and arsenal as well as their own. The helicopters, snipers, tanks, and CS gas turned what had begun on February 28, as a raid to serve a search warrant, into a full scale military-style attack on a stubborn fortress and its peoples.

The federal agents became the tools they were using. Really, the tools were using them. Prior to the initial raid, some ATF agents were instructed by military personnel to write their blood types on their necks and legs (Chunn 2000). Pataphysically, it might be said that the objects seductively overcame the subjects and the subjects were used to do the objects' bidding. Baudrillard (2000:75) says that the object has "a perverse strategy; perhaps it is a form of revenge. Apparently, the object is a trickster...[whereby] the subject itself loses its position as subject." In seeking an explanation for the tragic unfolding at Mount Carmel, sociologist Thomas Robbins and his colleague, forensic psychologist Dick Anthony (1995:237-238), unwittingly prove the point that the conflagration had less to do with the subjects, the Davidians, or even their stockpiling of weapons, and more to do with the powerful objects, like the tanks and CS gas. They state:

[T]o set off the immolations in Waco (assuming that the Davidians were responsible for setting the fire), what had to transpire was not only the initial militarystyle raid on the "cult compound" by the Bureau of Alcohol, Tobacco, and Firearms but also the subsequent breaking down of the walls of the compound by armored vehicles and the insertion of CS gas. (italics added)

The FBI didn't topple that building and inject it full of the toxic and volatile CS gas-the tanks did. Contained within the tanks is the fulfillment of their ruse, 
regardless of any subject that takes itself to be at the helm. Could it be that the tanks seduced the subjects into fulfilling their evil plan?

\section{CONCLUSION}

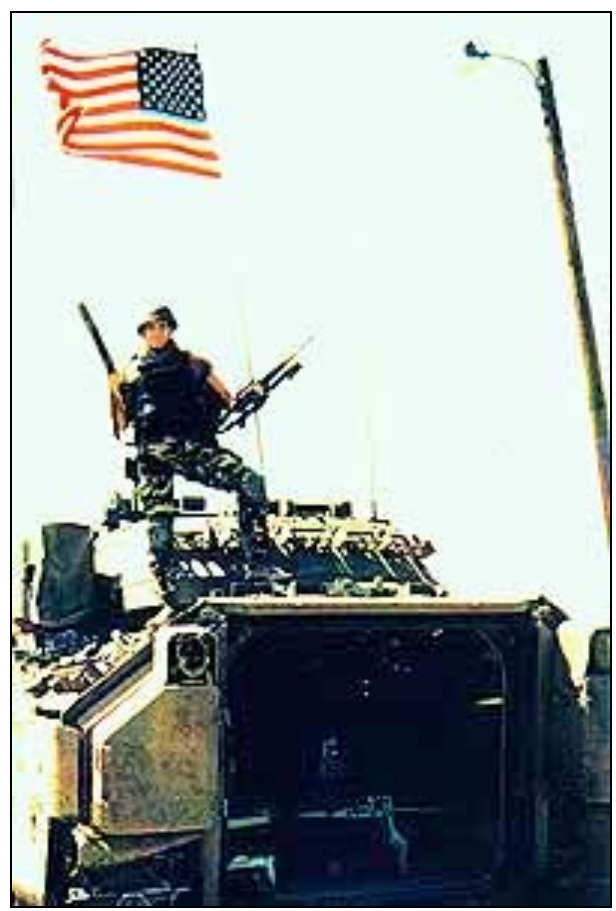

Figure 5: Evidence photo of $\mathrm{FBI}$ agent on tank (Waco: The Rules of Engagement 2010b).

Watching the archived media footage of the 51-day standoff, the atmosphere markedly shifts as we see the FBI unloading Abrams tanks borrowed from the armed forces. If there is any proof that the subject's sovereignty is slipping into the control of the object it is this: Once the tanks rolled in, how could the standoff have ended any other way?

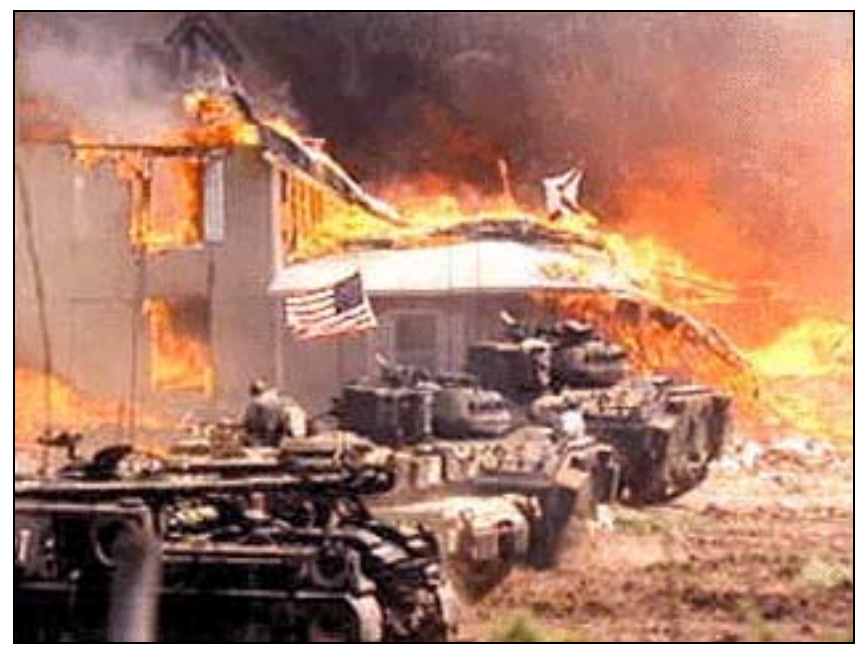

Figure 6: Evidence photo of tanks' invasion (Waco: The Rules of Engagement 2010c).
One last image haunts the smoking rubble: On the compound's main flagpole, which had previously held Koresh's Star of David flag, the American, Texas, and ATF flags flew at half-staff (Gibbs et al. 1993:8). The federal agencies were indeed advertising their victory, strutting for the media outlets that had been perched at a distance. But maybe the flags knew the real victor: the objects themselves.

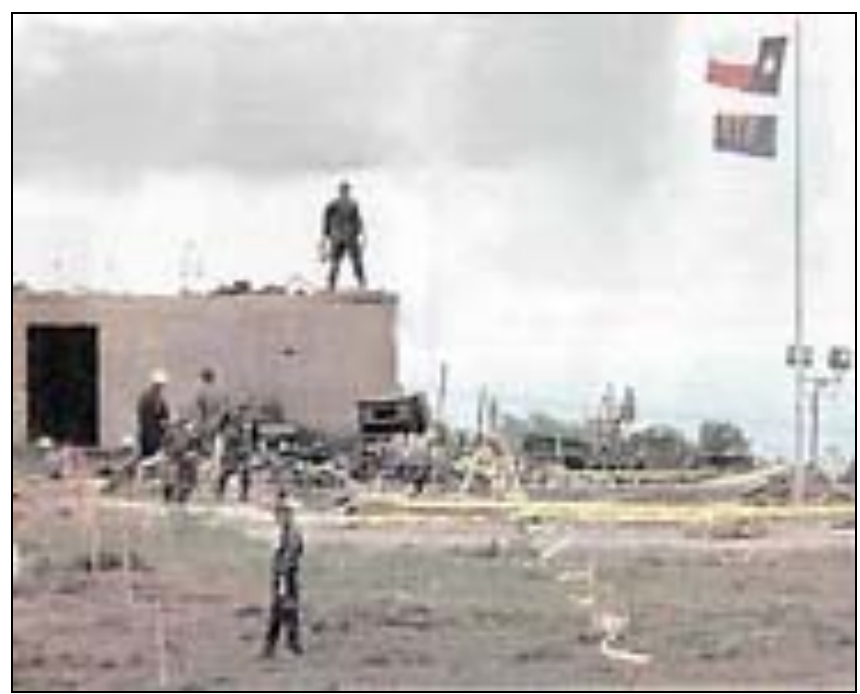

Figure 7: Evidence photo of Texas and ATF flags after the siege (Waco: The Rules of Engagement 2010a).

\section{REFERENCES}

Baudrillard, Jean. [1987] 1988a. The Ecstasy of Communication. Translated by B. Schutze and C. Schutze. New York: Semiotext(e).

Baudrillard, Jean. 1988b. Jean Baudrillard: Selected Writings. Edited by M. Poster. Stanford, CA: University Press.

Baudrillard, Jean. [1983] 1990. Fatal Strategies. Translated by P. Beitchman and W. G. J. Niesluchowski. New York: Semiotext(e).

Baudrillard, Jean. 2000. The Vital Illusion. Edited by J. Witwer. New York: Columbia University Press.

BBC News. 1993. "Waco Cult Siege Ends with Inferno." Image (JPEG). Retrieved July $5, \quad 2012$ (http://news.bbc.co.uk/media/images/38481000/jpg/_384814 59_wacofire238.jpg).

BBC News. 1999. "Koresh and the Waco Siege." Image (JPEG). Retrieved July 8, 2012 (http://news.bbc.co.uk/2/hi/americas/431311.stm).

Becker, Ernest. [1962] 1971. The Birth and Death of Meaning: An Interdisciplinary Perspective on the Problem of Man. $2^{\text {nd }}$ ed. New York: The Free Press.

Chunn, Sherri. 2000. "More Testimony in Waco Case." Associated Press, July 5. Retrieved May 15, 2012 (http://www.cesnur.org/testi/waco97.htm).

Finkelstein, Joanne. 2007. The Art of Self-invention: Image and Identity in Popular Visual Culture. London: I. B. Tauris.

Gazecki, William. 1997. Waco: The Rules of Engagement. Fifth Estate Productions.

Gibbs, Nancy, Michael Riley, Richard Woodbury, Julie Johnson, and Elaine Shannon. 1993. "The Branch Davidians: Oh, My God, They're Killing Themselves!” Time, May 3, pp. 20-23. 
Robbins, Thomas and Dick Anthony. 1995. "Sects and Violence: Factors Enhancing the Volatility of Marginal Religious Movements." Pp. 236-259 in Armageddon in Waco: Critical Perspectives on the Branch Davidian Conflict, edited by S. A. Wright. Chicago: University Press.

Thibodeau, David and Leon Whiteson. 1999. A Place Called Waco: A Survivor's Story. New York: PublicAffairs.

Waco: The Rules of Engagement. 2010a. "Gallery Page 1." Images (JPEG). Retrieved July 9, 2012 (http://www.waco93.com/gallery?show=gallery).

Waco: The Rules of Engagement. 2010b. "Gallery Page 2." Images (JPEG). Retrieved July 9, 2012 (http://www.waco93.com/gallery?show=gallery\&nggpage=2).
Waco: The Rules of Engagement. 2010c. "Gallery Page 3." Images (JPEG). Retrieved July 9, 2012 (http://www.waco93.com/gallery?show=gallery\&nggpage=3).

Wright, Stuart A. 1995. "Construction and Escalation of a Cult Threat: Dissecting Moral Panic and Official Reaction to the Branch Davidians." Pp. 75-94 in Armageddon in Waco: Critical Perspectives on the Branch Davidian Conflict, edited by S. A. Wright. Chicago: University Press.

Received on 11-07-2012

Accepted on 26-09-2012

Published on 03-10-2012

DOI: http://dx.doi.org/10.6000/1929-4409.2012.01.7

(C) 2012 Michelle Granden; Licensee Lifescience Global.

This is an open access article licensed under the terms of the Creative Commons Attribution Non-Commercial License (http://creativecommons.org/licenses/by-nc/3.0/) which permits unrestricted, non-commercial use, distribution and reproduction in any medium, provided the work is properly cited. 